\title{
A new method for the validation of the GOMOS high resolution temperature profiles products
}

\author{
Rosario Q. Iannone ${ }^{1,{ }^{\star}}$, Stefano Casadio ${ }^{1,2}$, Bojan Bojkov ${ }^{2}$ \\ ${ }^{1}$ SERCO S.p.A., Frascati, Italy \\ ${ }^{2}$ ESA/ESRIN, Frascati, Italy
}

\author{
Article history \\ Received January 10, 2014; accepted September 18, 2014. \\ Subject classification: \\ Gomos HRTP, Atmospheric waves, Temperature profiles, Validation, Wavelet transform.
}

\begin{abstract}
This article proposes a new validation method for GOMOS HRTP atmospheric temperature and density profiles, with the aim of detecting and removing 0.2 to $5 \mathrm{~km}$ scale vertical structures in order to minimise the impact of atmospheric artefacts in the comparison exercises. The proposed approach is based on the use of the "Morlet" Continuous Wavelet Transformation (CWT), for the characterisation and removal of non-stationary and localised vertical structures, in order to produce wave-free profiles of atmospheric temperature and density. Comparison of wavefree temperature/density profiles and wavy structures profiles with those estimated from a limited number of collocated SHADOZ soundings for the years of 2003, 2004 and 2008, is discussed in detail. First results suggest that the proposed approach could lead to a significantly improved HRTP validation scheme, in terms of reduced uncertainties in the estimated biases. Furthermore, this method may be adopted for the study of the vertical component of gravity waves from high spatial/temporal resolution data.
\end{abstract}

\section{Introduction}

The accurate knowledge of the temporal and spatial structure of atmospheric temperature and neutral density profiles over a broad vertical range is essential for the understanding of both climate and weather mechanisms [Alpers et al. 2004].

Measurements of temperature profiles have been performed over 60 years, based on a variety of instruments and techniques, such as sondes [Tiefenau and Gebbeken 1989, Hudson et al. 2004], ground based infrared sounders [Knuteson et al. 2004a, 2004b], and lidars (Light Detection and Ranging) [Hauchecorne and Chanin 1980, Thompson et al. 2012]. Developing a reliable meteorology and climatology requires frequent measurements with good spatial coverage and resolution. Since 1979, observations have been available from satellites orbiting around the Earth [Spencer et al. 1990], thus providing data with global coverage, which is often lacking in other data sets. A limitation of space-borne passive remote sensing instruments is the relatively low vertical resolution (of the order of kilometres), while ground based active instruments and in-situ measurements can have very high vertical resolution (i.e. few meters), but they are limited to regional studies and the related datasets can be sparse in time. In particular, balloon-borne experiments provide measurements of temperature profiles from ground up to the maximum altitude reached by the balloon, which is usually at $\sim 30$ $35 \mathrm{~km}$ [Durre et al. 2006], with a vertical resolution varying between 5 and $50 \mathrm{~m}$. On the other hand, spaceborne experiments, such as the Microwave Limb Sounder (MLS) [Wu and Waters 1996], the Halogen Occultation Experiment (HALOE) on-board Upper Atmosphere Research Satellite (UARS) [Borchi et al. 2005], the Michelson Interferometer for Passive Atmospheric Sounding (MIPAS) [Ridolfi et al. 2007] on-board ENVISAT, the High Resolution Dynamics Limb Sounder (HIRDLS) on the AURA spacecraft [Dials et al. 1998], the Sounding of the Atmosphere by Broadband Emission Radiometry (SABER) on TIMED (Thermosphere Ionosphere Mesosphere Energetics Dynamics) satellite [Kumar et al. 2008] and GPS radio occultation technique [Kursinski et al. 1997, Schreiner et al. 2007] as the Constellation Observing System for Meteorology Ionosphere and Climate (COSMIC / FORMOSAT-3) satellite [Kishore et al. 2009], have been designed to retrieve temperature profiles in a wide altitude range, from troposphere to mesosphere, but with a vertical resolution much lower when compared to that of balloon sondes. An exception is represented by the High Resolution Temperature Profile (HRTP) of GOMOS (Global Ozone Monitoring by Occultation of Stars) tempera- 
ture and density products [Bertaux et al. 2010], which have a vertical sampling of few tens of meters and an estimated vertical resolution of about $250 \mathrm{~m}$ (see Sofieva et al. [2007a, 2007b]).

The aim of the present study is the development of technique to be applied to GOMOS HRTP and to high resolution correlative data (e.g. sondes) before comparing them. In particular, our objective is to remove as much as possible the small-scale fluctuations from the temperature and density profiles and consequently to increase the accuracy on estimates of biases.

The method is based on the hypothesis that vertical fluctuations in both temperature and density profiles are due to the presence of atmospheric waves, and that the time-space lags between satellite and balloon measurements are the causes for "vertical phase shifts" of such waves which is, in turn, largely impacting the validation results by introducing spurious signals.

In this context, we developed an analysis approach, which is designed to detect and remove the wavy signals from both the Satellite and correlative instrument temperature and density profiles prior to compare them. This method has been tested using the GOMOS HRTP and the SHADOZ measurements.

\section{Gravity waves observed in temperature profiles: implication for validation}

Data comparison between space observations and in-situ measurements, such as airborne instrument, balloons and lidars, is a critical part of satellite validation and of verification of theoretical models [Hendrick et al. 2011]. The necessity to exchange and compare data between Earth Observation sensors and ground measurements communities has led to coordinated efforts in Calibration and Validation (Cal/Val) methodologies. Validation entails comparison of references with 'known' or expected values, determined with long-term and continuous calibration measurements. Two validation approaches are usually followed. The first is based on the use of data provided by ground-based networks, test sites, and instruments intercomparison systems, which run independently of a specific satellite mission. A second approach is based on field campaigns designed for specific validation needs. Cal/Val campaigns provide a unique set of high quality observations that are used for the validation of retrievals from the satellites. However dedicated airborne and balloon instruments usually only provide snap-shot observations, providing more detailed regional information. In contrast, satellite-based remote measurements are complementary as they have regional to global coverage.

The effects due to increase of the time/space separation between temperature/density profile pairs, in terms of accuracy of comparison results, is dominated by geophysical variations. Small-scale vertical structures present in the vertical temperature profiles, significantly impact the effectiveness of the validation studies if not properly treated. In fact, these structures are usually highly non-stationary, complicating the validation studies with the introduction of a variability that cannot be attributed to instrumental/algorithmic deficiencies [Sofieva et al. 2008]. These relatively small-scale structures in atmospheric temperature and density profiles are often interpreted as due to gravity waves [Sofieva et al. 2008].

The main sources for gravity waves in the lower and middle atmospheres are topography, orography, convection and jet/front systems [Fritts and Alexander 2003]. Moreover, gravity waves are perturbations resulting from the coupling mechanism between lower, middle, and upper atmospheric region. Vertically propagating gravity waves, generated in the troposphere, carry fluxes of heat and momentum into the stratosphere [Holton and Mass 1976]. When these waves are damped, the fluxes diverge, and sources of heat and momentum are created, thus providing the acceleration of the wind in the upper atmosphere and well above in the stratosphere and mesosphere. The net effect of the wave breaking is the acceleration of movement of air masses towards the poles, and an ascending motion in the tropical tropopause. Gravity wave dissipation in the stratosphere contributes to driving large scale circulations like the Brewer-Dobson circulation [Holton and Alexander 2000].

Numerous studies have been published, describing techniques using temperature profiles as tracers to understand internal gravity waves, using radiosonde [Zink and Vincent 2001], balloon data [Zhang et al. 2006], lidar data [Rauthe et al. 2008], and satellite data [Fetzer and Gille 1994]. A review of the studies on gravity-wave effects in stratosphere, recent observations, analysis methods, and results of very-high-resolution model studies have recently been reported by Alexander et al. [2010]. In the context of space-borne techniques, Preusse et al. [2009] demonstrated that observations from an infrared limb imager (ILI) may provide 3-D images of gravity waves temperature structures, thanks to recent advances in detector technology.

McDonald et al. [2010] used vertical temperature measurements from radio occultation (RO) satellites in the FORMOSAT 3/COSMIC constellation, and from Rayleigh lidar observations, to study the variation of stratospheric temperature as a function of spatial and temporal separation.

Alexander et al. [2008] described a global analysis of the High Resolution Dynamics Limb Sounder (HIRDLS) temperature profile data to derive properties of gravity 
waves. Later in 2011, an inter comparison of HIRDLS, COSMIC and SABER was carried out by Wright et al. [2011], with the aim of detecting stratospheric gravity waves from collocated temperature profiles. In the particular case of Alexander et al. [2008] and Wright et al. [2011], a Stockwell Transform (S-Transform) based method was employed for the detection of gravity waves to allow the detection of multiple overlapping waves. The S-transform combines the Short Time Fourier Transform (STFT) and wavelet transforms. In particular, the S-transform is expressed as a Continuous Wavelet Transformation (CWT) with a specific mother wavelet multiplied by a phase factor, in order to achieve information related not only to the spectral properties of the signal but also information related to the spatial variations in those spectral properties. A detailed description of the S-Transform method can be found in the publication of Stockwell et al. [1996].

Finally, Geller et al. [2013] used five datasets from HIRDLS instrument on the Aura satellite, SABER instrument on the TIMED satellite, VORCORE super-pressure balloon, and high resolution radiosonde sounding of horizontal wind and temperature. The aim of their work was to estimate the gravity wave momentum fluxes from the above mentioned observations and from those derived from five different models. The use of these measurements allowed testing theoretical models, and in particular to make these models able to correctly describe gravity wave sources.

Analysing the GOMOS scintillation spectra, Sofieva et al. [2007a, 2007b] demonstrated the existence of a direct relationship between the stellar scintillations and small-scale internal gravity waves and turbulence. This approach is based on the fact that stellar scintillations observed through the Earth's atmosphere are caused by air density irregularities and thus they contain information about small-scale processes in the atmosphere such as gravity waves and turbulence. Reconstruction of gravity waves could be achieved by fitting modelled scintillation spectra to the GOMOS measured spectra [Sofieva et al. 2007a, 2010].

Validation work relevant to GOMOS HRTP has been reported in literature by Sofieva et al. [2009]. The GOMOS HRTP products, output of the scientific processor, were validated with collocated SHADOZ data by comparing vertical wavenumber spectra of temperature fluctuations [Sofieva et al. 2009].

The approach proposed in this work is based on a wavelet transform of the air density and temperature profiles directly, for both GOMOS and SHADOZ, soundings, demonstrating that this "wave-cleaning" technique improves the profiles validation schemes by reducing the impact of "out of phase" wavy structure in the estimates of biases. In the stratosphere, the temperature perturbation amplitudes can be of the order of 5-10 K. As a consequence, two waves out of phase by half wavelength will produce a difference in temperature profiles of the order of 10-20 K. Assuming a temperature profile to consist of a background temperature profile and fluctuating components, the idea is therefore to validate collocated background temperature profiles, after eliminating the perturbation profiles.

\section{Data description}

\subsection{SHADOZ radiosonde}

The Southern Hemisphere Additional Ozonesondes network (SHADOZ) (http: / / croc.gsfc.nasa.gov/ shadoz/; Thompson et al. [2003a, 2003b]) was initiated by NASA in 1998, aiming at the provision of continuous and accurate balloon measurements taken at 14 tropical selected locations, with the main purpose to measure the profile of ozone from sea level to about $30 \mathrm{~km}$ altitude from $40 \mathrm{~S}$ to $40 \mathrm{~N}$ latitude. Besides ozone, temperature, pressure, and relative humidity are retrieved. The ozone measurements are performed with electrochemical concentration cells, while temperatures and pressures are recorded by standard Vaisala instrumentation [Thompson et al. 2004, 2007]. Ozonesondes are launched from SHADOZ stations on a weekly basis, during both day time and night time [Thompson et al. 2003a].

The SHADOZ data are usually sampled at $0.5 \mathrm{~Hz}$ intervals resulting in a vertical resolution of about $10 \mathrm{~m}$. For the sonde types used in the tropics, systematic errors in temperature data are $\pm 0.3 \mathrm{~K}$, with a precision of 0.2 $0.4 \mathrm{~K}$ [Thompson et al. 2003a, WMO 2008]. The retrieval of atmospheric temperature with balloon-borne instruments is affected by a combination of errors [Christy and Norris 2009]. Sensor limitation is not the only source of uncertainties, as the representativeness error plays an important role [Kitchen 1989]. In fact, balloon sounding consists of point measurements along a path through the atmosphere and, on average, a balloon needs more than $60 \mathrm{~min}$ to reach $15 \mathrm{~km}$ height [Moradi et al. 2010]. Thus, during its ascent, a balloon would drift because of the horizontal wind, therefore providing profiles that cannot be considered rigorously vertical [Lanzante et al. 2003].

For this study, SHADOZ stations have been selected according to the criteria of the highest number of collocations and the maximum altitude reached by the balloons, usually ranging between 30 and $35 \mathrm{~km}$. The data sets analysed are from the years 2003, 2004, and 2008. The selected four near-equatorial stations are Java, Kuala, Ascension Island, and Hilo. Details of the available data sets used in this work for the four stations are given in Table 1. 


\begin{tabular}{|c|c|c|c|c|c|}
\hline No. & $\begin{array}{l}\text { Shadoz date } \\
\text { (Launch time) }\end{array}$ & $\begin{array}{l}\text { Shadoz stations } \\
\text { (Lat. and Long.) }\end{array}$ & $\begin{array}{c}\text { GOMOS } \\
\text { Lat. and Long. (date) }\end{array}$ & $\begin{array}{c}\text { Star id } \\
\left(\mathbf{m}_{\mathrm{v}} ; \mathbf{t}_{\mathrm{v}}[\mathrm{K}]\right)\end{array}$ & $\begin{array}{c}\Delta \mathrm{h}(\mathrm{km}) \\
\Delta \mathrm{t}(\mathrm{h})\end{array}$ \\
\hline 1 & $\begin{array}{c}20030108 \\
(09: 38)\end{array}$ & $\operatorname{Java}\left(7^{\circ} 5^{\prime} \mathrm{S}, 112^{\circ} 6^{\prime} \mathrm{E}\right)$ & $\begin{array}{l}6^{\circ} 1^{\prime} \mathrm{S}, 112^{\circ} 8^{\prime} \mathrm{E} \\
(2003010822: 32)\end{array}$ & $\begin{array}{c}78 \\
(2.3 ; 28000)\end{array}$ & $\begin{array}{c}119 \\
13\end{array}$ \\
\hline 2 & $\begin{array}{c}20031224 \\
(02: 17)\end{array}$ & Java $\left(7^{\circ} 5^{\prime} \mathrm{S}, 112^{\circ} 6^{\prime} \mathrm{E}\right)$ & $\begin{array}{l}8^{\circ} 3^{\prime} \mathrm{S}, 105^{\circ} 4^{\prime} \mathrm{E} \\
(2003122323: 03)\end{array}$ & $\begin{array}{c}95 \\
(2.5 ; 26000)\end{array}$ & $\begin{array}{l}783 \\
3.14\end{array}$ \\
\hline 3 & $\begin{array}{l}20040121 \\
(02: 42)\end{array}$ & Java $\left(7^{\circ} 5^{\prime} S, 112^{\circ} 6^{\prime} \mathrm{E}\right)$ & $\begin{array}{l}4^{\circ} 5^{\prime} \mathrm{S}, 107^{\circ} 5^{\prime} \mathrm{E} \\
(2004012122: 53)\end{array}$ & $\begin{array}{c}109 \\
(2.7 ; 26000)\end{array}$ & $\begin{array}{c}648 \\
20\end{array}$ \\
\hline 4 & $\begin{array}{c}20040219 \\
(02: 50)\end{array}$ & Java $\left(7^{\circ} 5^{\prime} S, 112^{\circ} 6^{\prime} \mathrm{E}\right)$ & $\begin{array}{l}9^{\circ} 8^{\prime} \mathrm{S}, 111^{\circ} 5^{\prime} \mathrm{E} \\
(2004021922: 40)\end{array}$ & $\begin{array}{c}80 \\
(2.8 ; 30000)\end{array}$ & $\begin{array}{c}254 \\
20\end{array}$ \\
\hline 5 & $\begin{array}{c}20040929 \\
(02: 41)\end{array}$ & Java $\left(7^{\circ} 5^{\prime} S, 112^{\circ} 6^{\prime} \mathrm{E}\right)$ & $\begin{array}{l}8^{\circ} 03^{\prime} \mathrm{S}, 113^{\circ} 3^{\prime} \mathrm{E} \\
(2004092922: 32)\end{array}$ & $\begin{array}{c}1 \\
(-1.4 ; 11000)\end{array}$ & $\begin{array}{l}150 \\
20\end{array}$ \\
\hline 6 & $\begin{array}{l}20080228 \\
(05: 27)\end{array}$ & Java $\left(7^{\circ} 5^{\prime} S, 112^{\circ} 6^{\prime} \mathrm{E}\right)$ & $\begin{array}{l}9^{\circ} 3^{\prime} \mathrm{S}, 111^{\circ} 3^{\prime} \mathrm{E} \\
(2008022822: 40)\end{array}$ & $\begin{array}{c}25 \\
(1.62 ; 28000)\end{array}$ & $\begin{array}{c}248 \\
17.13\end{array}$ \\
\hline 7 & $\begin{array}{c}20080828 \\
(05: 34)\end{array}$ & Java $\left(7^{\circ} 5^{\prime} \mathrm{S}, 112^{\circ} 6^{\prime} \mathrm{E}\right)$ & $\begin{array}{l}4^{\circ} 6^{\prime} \mathrm{S}, 107^{\circ} 4^{\prime} \mathrm{E} \\
(2008082714: 52)\end{array}$ & $\begin{array}{c}2 \\
(-0.74 ; 7000)\end{array}$ & $\begin{array}{c}648 \\
14\end{array}$ \\
\hline 8 & $\begin{array}{c}20080828 \\
(05: 34)\end{array}$ & Java $\left(7^{\circ} 5^{\prime} S, 112^{\circ} 6^{\prime} \mathrm{E}\right)$ & $\begin{array}{l}4^{\circ} 2^{\prime} \mathrm{S}, 115^{\circ} 3^{\prime} \mathrm{E} \\
(2008082822: 21)\end{array}$ & $\begin{array}{c}2 \\
(-0.74 ; 7000)\end{array}$ & $\begin{array}{c}470 \\
17\end{array}$ \\
\hline 9 & $\begin{array}{c}20080924 \\
(05: 27)\end{array}$ & Java $\left(7^{\circ} 5^{\prime} S, 112^{\circ} 6^{\prime} \mathrm{E}\right)$ & $\begin{array}{l}10^{\circ} 1^{\prime} \mathrm{S}, 105^{\circ} 9^{\prime} \mathrm{E} \\
(2008092423: 11)\end{array}$ & $\begin{array}{c}23 \\
(1.50 ; 26000)\end{array}$ & $\begin{array}{c}830 \\
18\end{array}$ \\
\hline 10 & $\begin{array}{l}20030122 \\
(03: 40)\end{array}$ & Kuala $\left(2^{\circ} 73^{\prime} \mathrm{N}, 101.7 \mathrm{E}\right)$ & $\begin{array}{l}3^{\circ} 8^{\prime} \mathrm{N}, 97^{\circ} 6^{\prime} \mathrm{E} \\
(2003012223: 35)\end{array}$ & $\begin{array}{c}54 \\
(2.05 ; 4500)\end{array}$ & $\begin{array}{l}446 \\
20\end{array}$ \\
\hline 11 & $\begin{array}{c}20030409 \\
(02: 06)\end{array}$ & Kuala $\left(2^{\circ} 73^{\prime} \mathrm{N}, 101.7 \mathrm{E}\right)$ & $\begin{array}{c}4^{\circ} 02^{\prime} \mathrm{N}, 101^{\circ} 3^{\prime} \mathrm{E} \\
(2003040923: 15)\end{array}$ & $\begin{array}{c}57 \\
(2.07 ; 26000)\end{array}$ & $\begin{array}{c}200 \\
21\end{array}$ \\
\hline 12 & $\begin{array}{c}20030401 \\
(20: 06)\end{array}$ & Hilo $\left(19^{\circ} 4^{\prime} \mathrm{N}, 155^{\circ} 1^{\prime} \mathrm{W}\right)$ & $\begin{array}{l}20^{\circ} 1^{\prime} \mathrm{N}, 150^{\circ} 3^{\prime} \mathrm{W} \\
(2003033121: 48)\end{array}$ & $\begin{array}{c}40 \\
(1.86 ; 7100)\end{array}$ & $\begin{array}{c}531 \\
22\end{array}$ \\
\hline 13 & $\begin{array}{l}20030410 \\
(21: 46)\end{array}$ & Hilo $\left(19^{\circ} 4^{\prime} \mathrm{N}, 155^{\circ} 1^{\prime} \mathrm{W}\right)$ & $\begin{array}{c}17^{\circ} 5^{\prime} \mathrm{N}, 154^{\circ} 1^{\prime} \mathrm{W} \\
(2003040922: 05)\end{array}$ & $\begin{array}{c}38 \\
(1.84 ; 11000)\end{array}$ & $\begin{array}{c}245 \\
24\end{array}$ \\
\hline 14 & $\begin{array}{c}20041011 \\
(13: 50)\end{array}$ & $\begin{array}{l}\text { Ascension Island } \\
\left(7^{\circ} 98^{\prime} \mathrm{S}, 14^{\circ} 4^{\prime} \mathrm{W}\right)\end{array}$ & $\begin{array}{l}10^{\circ} 7^{\prime} \mathrm{S}, 17^{\circ} 6^{\prime} \mathrm{W} \\
(2004101122: 17)\end{array}$ & $\begin{array}{c}65 \\
(2.2 ; 4400)\end{array}$ & $\begin{array}{c}408 \\
9\end{array}$ \\
\hline 15 & $\begin{array}{c}20080108 \\
(14: 10)\end{array}$ & $\begin{array}{l}\text { Ascension Island } \\
\left(7^{\circ} 98^{\prime} \mathrm{S}, 14^{\circ} 4^{\prime} \mathrm{W}\right)\end{array}$ & $\begin{array}{l}11^{\circ} 5^{\prime} \mathrm{S}, 14^{\circ} 6^{\prime} \mathrm{W} \\
(2008010822: 05)\end{array}$ & $\begin{array}{c}109 \\
(2.7 ; 26000)\end{array}$ & $\begin{array}{c}343 \\
8\end{array}$ \\
\hline 16 & $\begin{array}{c}20080826 \\
(14: 00)\end{array}$ & $\begin{array}{l}\text { Ascension Island } \\
\left(7^{\circ} 98^{\prime} \mathrm{S}, 14^{\circ} 4^{\prime} \mathrm{W}\right)\end{array}$ & $\begin{array}{l}5^{\circ} 05^{\prime} \mathrm{S}, 8^{\circ} 9^{\prime} \mathrm{W} \\
(2008082521: 38)\end{array}$ & $\begin{array}{c}2 \\
(-0.74 ; 7000)\end{array}$ & $\begin{array}{c}763 \\
16\end{array}$ \\
\hline
\end{tabular}

Table 1. Overview of the time and geolocation of SHADOZ measurements and GOMOS available for this study. The table reports also the visual magnitude and effective temperature of stars of which GOMOS products are presented.

\subsection{GOMOS}

GOMOS was an instrument on-board the ENVISAT (ENVIronmental SATellite) satellite, successfully operated by ESA (European Space Agency) from March 2002 to April 2012. GOMOS used the Star Occultation technique in the ultraviolet-visible-nearinfrared (UV-VIS-NIR) spectral range to retrieve vertical profiles of atmospheric parameters. In particular, GOMOS was designed to monitor vertical distribution of $\mathrm{O}_{3}, \mathrm{NO}_{2}, \mathrm{NO}_{3}, \mathrm{O}_{2}, \mathrm{H}_{2} \mathrm{O}$, atmospheric density and aerosols, and HRTP [Bertaux et al. 2004, Kyrölä et al. 2004, Kyrölä et al. 2006]. The HRTP is retrieved from the scintillation observed by two GOMOS fast-photometer measurements, operating at $1 \mathrm{kHz}$ sampling frequency in the blue $(470-520 \mathrm{~nm})$ and in the red (650$700 \mathrm{~nm}$ ) spectral regions [Bertaux et al. 2010]. The bichromatic scintillations recorded by the photometers allow the determination of refractive angles, which are related to the time delays between the photometer signals. The high resolution density and temperature profiles can be derived from these data in the $18-35 \mathrm{~km}$ altitude range, following the method described in Dalaudier et al. [2006]. The vertical sampling of these products is of the order of tens of meters, with an estimated resolution of about $250 \mathrm{~m}$.

For altitudes between 18 and $35 \mathrm{~km}$, the estimated accuracy of the HRTP is between 1 and $2 \mathrm{~K}$ [Sofieva et al. 2009]. 
The GOMOS HRTP data used in this study were generated with the Instrument Processor Facility (IPF) version 6.01 , and have been publicly available since December 2012.

The quality of HRTP is nearly independent of the star properties, like the visual magnitude $\left(\mathrm{m}_{\mathrm{v}}\right)$ and the temperature $\left(\mathrm{t}_{\mathrm{v}}\right)$. It is also independent of the obliquity angles (i.e. the angle between the direction of line of sight motion and the local vertical at the ray perigee point) but it slightly depends upon illumination conditions. The highest quality HRTP data are acquired in dark limb, i.e. for nocturnal occultations. On the illuminated portion of the orbit, scattered solar light impacts the data quality in the lower stratosphere, so that only very bright stars provide full stratospheric profiles in these conditions.

\subsection{Collocation criteria}

We have restricted all collocations to a maximum horizontal distance of $800 \mathrm{~km}$ and a maximum time difference of $24 \mathrm{~h}$ between measurements. Although validation protocols require the comparison of measurements of the same air mass, we adopted such relaxed spatial and temporal coincidence criteria in order to obtain a sufficient number of collocations to test our method in terms of wave detection. The observations used in the present study include 16 collocated vertical profiles, among which were six profiles for 2003, four for 2004 and finally six collocated vertical profiles for 2008.

Besides the geolocation of paired GOMOS and SHADOZ profile, Table 1 reports the star parameters $\left(\mathrm{m}_{\mathrm{v}}\right.$ and $\left.\mathrm{t}_{\mathrm{v}}\right)$ and the spatial/temporal distance for each collocation.

In order to effectively compare satellite and balloon data, we adopted a common vertical grid of $100 \mathrm{~m}$ by applying a linear interpolation scheme to both GOMOS and SHADOZ data, and excluding from the wavelet analysis any fluctuation with vertical wavenumber $>0.01 \mathrm{~m}^{-1}$.

It is stressed here, that this work is not intended to provide conclusive validation results, but to propose a validation method. Thus, a limited dataset should be sufficient to prove the effectiveness of the proposed approach. The analysis of the complete GOMOS mission dataset will be carried out in the next future.

\section{Method description}

In order to remove the small-scale fluctuations from the SHADOZ and GOMOS temperature profiles, both profiles were analysed by using the Coherence Wavelet Method (CWM) software developed by Torrence and Compo (Torrence and Compo [1998]; http:/ / paos.colorado.edu/research/wavelets/). The compo- nents and method of this wavelet tool are not described here; readers are referred to Torrence and Compo [1998] for a more detailed explanation of the wavelet analysis. However, we include here some overall information about the wavelet transformation.

In general, the continuous wavelet transform analysis is a time/space-dependent spectral analysis that decomposes a data series in time/space-frequency domain. In this, the scaled wavelet progressively moves along the time (or space)-varying signal, detecting localized structures in the signal. The most commonly adopted method for the spectral analysis of wavy signals is the Fast Fourier Transform (FFT). The FFT, however, is suitable for the retrieval of spectral information for stationary signals only, which are quite rare phenomena in the real atmosphere. The ability to detect and characterise time and space localised phenomena is fundamental for gravity wave analysis, and this can be achieved by using the wavelet transformation.

Time windowing and Fourier analysis techniques require a priori understanding of the signal and, consequently, it is necessary to make assumptions about the nature of the phenomenon under study. In addition, applying time/space Fourier technique requires an averaging time long enough to obtain significant statistical parameters on a selected window short enough that a slowly varying signal appears to be stationary. Wavelet techniques represent valid alternatives to the time windowing method with the advantage of needing minimum knowledge of the analytical properties of the signal.

By definition, the wavelet function $\Psi$ is constructed so that it has zero mean and is localized both in time/space and in frequency. The wavelet type used in this work for the spectral decomposition is the Mother Wavelet Function (MWF). The MWF is shifted forward and backward in the time/space domain, and this process is repeated for different frequency wavelets by stretching and compressing the MWF. Different MWF have been developed and the choice of a function depends on both the desired analysis and the nature of the time/space series analysed.

In this study, the Morlet MWF was selected because it provides information about both amplitude and phase at the highest vertical resolution, and is better suited for data with oscillatory behaviour. The Morlet MWF is defined as a sinusoidal function multiplied by a Gaussian function [Torrence and Compo 1998]:

$$
\Psi(x)=\pi^{-\frac{1}{4}} e^{i \omega_{0} x} e^{\frac{\left(x-x_{0}\right)^{2}}{2 \sigma_{0}}}
$$

where $\omega_{0}$ is the non-dimensional frequency, $x$ is the independent variable, $x_{0}$ and $\sigma_{0}$ are the mean value and 


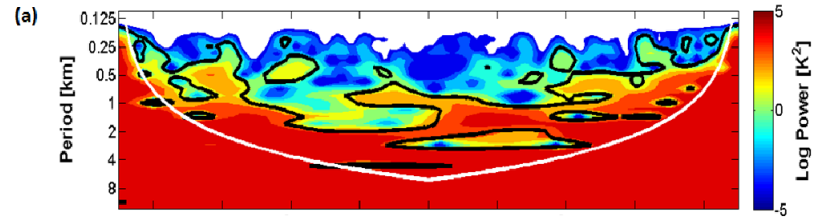

(b)

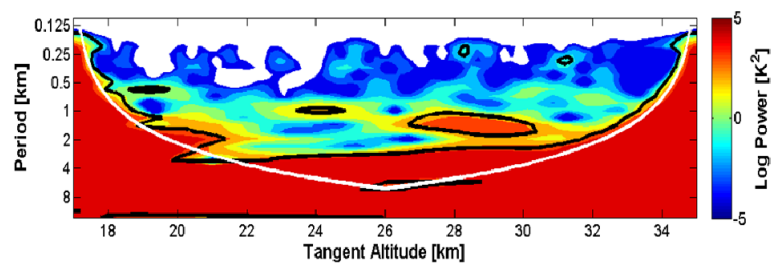

Figure 1. Wavelet power spectrum using Morlet mother wavelet for (a) GOMOS HRTP and (b) Radiosonde SHADOZ temperature profile illustrated in Figure 2. The black lines in both graphs contours the areas where the power is considered to exceed the $95 \%$ confidence level, whereas the white line contours the area defined by the Cone Of Influence (COI).

the width of the Gaussian function, respectively.

Usually, the wavelet transform is complex and is characterized in terms of its power and phase. The square modulus of the wavelet transform is called the scalogram. In the wavelet analysis, the mean power spectrum for each series investigated is processed first, and in case a peak in the wavelet power spectrum is significantly above a background power threshold, then it is considered to be a significant feature. Torrence and Compo [1998] proposed the calculation of a Cone Of Influence (COI), which determines the region of the spectrum where edge effects significantly impact the wavelet results. The COI represents therefore the space/frequency region where the wavelet power spectra values can be considered unbiased by edge effects. Figure $1 \mathrm{a}$ and b shows the wavelet scalogram of the GOMOS and SHADOZ temperature profiles respectively, shown in Figure 2. The two panels of Figure 1 show the logarithmic energy of spectral components as a function of vertical coordinate (abscissa) and of the oscillation period (ordinates); the COI is indicated with a solid white line. The values in the 2-D wavelet power spectrum that are above the $\mathrm{COI}$ (i.e. for period shorter than that indicated by the COI) can be assumed to be unaffected by edge effects. Each peak in the 2-D fields corresponds to a localised wavy structure. In this example, the wavelet analyses of GOMOS and SHADOZ temperature variations show dominant wave periods between 0.7 and 4 $\mathrm{km}$ around the height region from 22 to $32 \mathrm{~km}$. In fact, in both panels of Figure 1, short scale fluctuations of 1 $\mathrm{km}$ are seen in the $23-26 \mathrm{~km}$ height region, and vertical wavelength of $2.5 \mathrm{~km}$ is found in the $27-31 \mathrm{~km}$ height region. This spectral analysis of the profiles shows that the peaks of temperature fluctuations are comparable, even for profiles separated significantly in space and in time (hundreds of kilometres and several hours).
The inverse wavelet transform is, then, used to reconstruct the temperature fluctuations present in the observed temperature profiles, considering only wavelet components that are significantly within the COI. The reconstructed temperature fluctuations are subtracted from the original temperature profiles, thus providing "wave-free" profiles.

\section{Results and discussion}

Figure 2a shows an example of the interpolated temperature profiles acquired on October 11, 2004, by GOMOS and SHADOZ Radiosonde (Ascension station $14^{\circ} 42^{\prime} \mathrm{W}$ longitude and $7^{\circ} 98^{\prime} \mathrm{S}$ latitude, 15:00 Local Time). In the figure, the continuous black line represents the GOMOS HRTP, whereas the grey line is the SHADOZ data. HRTP was measured on the same day at 22:17 Local Time (23:17 UTC) over a close location ( $17^{\circ} 6^{\prime} \mathrm{W}$ Longitude and $10^{\circ} 7^{\prime} \mathrm{S}$ latitude). The star for this occultation is Lam Vel, which is considered cold $\left(\mathrm{t}_{\mathrm{v}}=4400 \mathrm{~K}\right)$ and of medium brightness $\left(\mathrm{m}_{\mathrm{v}}=2.2\right)$.

The temperature values of HRTP span from 200 to $250 \mathrm{~K}$, while the full range of SHADOZ temperature measurements is between $195 \mathrm{~K}$ and $245 \mathrm{~K}$. The temperature difference as a function of the altitude is given in Figure $2 \mathrm{~b}$, which shows the difference between GOMOS and SHADOZ temperature profiles, defined as $\triangle T=T_{\text {GOMOS }}-T_{\text {SHADOZ }}$.

Between 20 and $25 \mathrm{~km}$ altitude, the temperature difference distribution has a mean value $<\Delta T>$ of +1.30 and a standard deviation of $\pm 3.49 \mathrm{~K}$, whereas between 25 and $30 \mathrm{~km}$ altitude, $\langle\Delta T\rangle$ is +0.52 with a standard deviation of $\pm 4.02 \mathrm{~K}$. Finally, between 30 and $\sim 35 \mathrm{~km}$

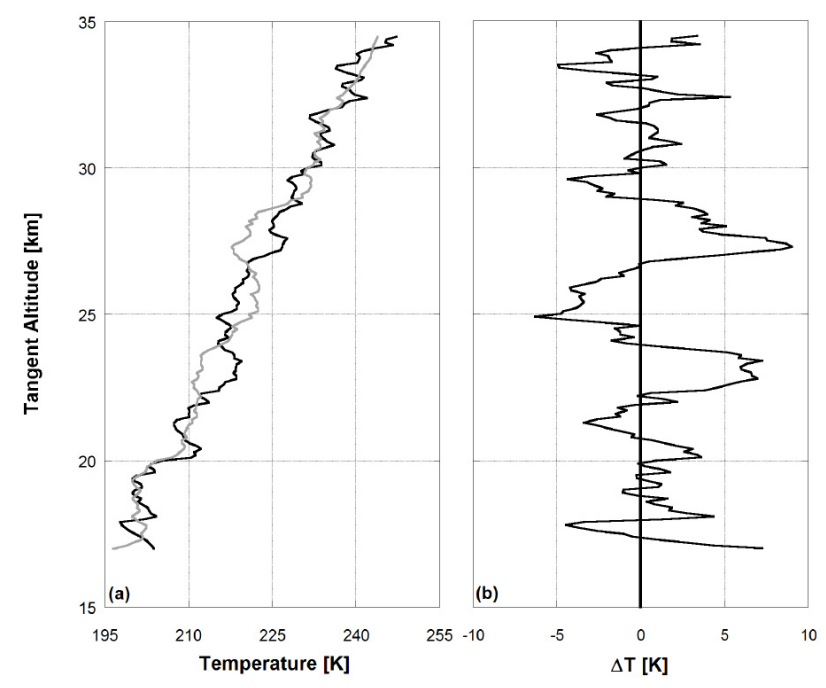

Figure 2. (a) original temperature profiles for GOMOS HRTP (black line) acquired on October $11,2004,22: 17 \mathrm{LT}\left(10^{\circ} 7^{\prime} \mathrm{S}, 17^{\circ} 6^{\prime}\right.$ W), for SHADOZ (gray line) measured on the same day at 13:50 LT, above Ascension Island $\left(7^{\circ} 98^{\prime} \mathrm{S}, 14^{\circ} 4^{\prime} \mathrm{W}\right)$; (b) absolute temperature difference between GOMOS and SHADOZ temperature profiles: $\triangle T=T_{\text {GOMOS }}-T_{\text {SHADOZ }}$. 
altitude, the $<\Delta T>$ is -0.01 with a standard deviation of $\pm 2.04 \mathrm{~K}$. The observed standard deviation of $\Delta T$, estimated between 18 and $35 \mathrm{~km}$ is $\pm 3.20 \mathrm{~K}$. Differences between GOMOS and SHADOZ profiles are due to several factors, such as data sampling, observation time and distance between profiles. Large differences, especially in the altitude range between 20 and $30 \mathrm{~km}$, are due to the fluctuating structures present in the GOMOS and SHADOZ temperature profiles, clearly visible in Figure 2, with amplitudes as large as $\pm 5 \mathrm{~K}$.

Figure 3 a shows the wave-free profile after applying the wave screening technique, and Figure $3 \mathrm{~b}$ shows the profile of residuals. After removing the wavy features present in the temperature profiles of Figure 1a, the agreement between wave-free GOMOS and SHADOZ temperature profiles is very good. Differently from the case shown in Figure $2 \mathrm{~b}$, where the $\Delta T$ was continuously changing sign with height, in Figure $3 \mathrm{~b}$ it is clear that GOMOS shows a deviation relative to SHADOZ of $\sim 1 \mathrm{~K}$ in the stratosphere up to $30 \mathrm{~km}$. In comparison to SHADOZ data, the highest altitudes show a small underestimation of the temperature by GOMOS.

In Table 2, values of mean of the temperature difference distribution $\langle\Delta T\rangle$ and related standard deviation are reported for each altitude range. For the wave-free profiles, $<\Delta T>$ is $+1.12 \pm 0.60 \mathrm{~K}$ for $20-25 \mathrm{~km}$ altitude range, $+0.80 \pm 0.22 \mathrm{~K}$ between 25 and $30 \mathrm{~km}$, and $-0.48 \pm 1.22 \mathrm{~K}$ between 30 and $\sim 35 \mathrm{~km}$, respectively. For the full range of altitude, $<\Delta T>$ is $+0.53 \pm 0.98 \mathrm{~K}$.

By applying the proposed method to the original temperature profiles shown in Figure 2, the standard deviation of the differences between the wave-free GOMOS and SHADOZ profile, for this particular case, decreases by a factor of $\sim 8$ in the altitude range from 20 up to $30 \mathrm{~km}$, then by a factor of almost 2 between 30 and $\sim 35 \mathrm{~km}$. Finally the overall standard deviation is decreased by a factor of about 3 . Thus, the difference

\begin{tabular}{ccc}
\hline $\begin{array}{c}\text { Altitude } \\
\text { range } \\
(\mathbf{k m})\end{array}$ & $\begin{array}{c}<\Delta \mathrm{T}> \pm 1 \sigma(\mathrm{K}) \\
\text { before } \\
\text { wavelet analysis }\end{array}$ & $\begin{array}{c}<\Delta \mathrm{T}> \pm 1 \sigma(\mathrm{K}) \\
\text { after } \\
\text { wavelet analysis }\end{array}$ \\
\hline $20-25$ & $+1.30 \pm 3.49$ & $+1.12 \pm 0.60$ \\
$25-30$ & $+0.52 \pm 4.02$ & $+0.80 \pm 0.22$ \\
$30-35$ & $-0.01 \pm 2.04$ & $-0.48 \pm 1.22$ \\
$18-35$ & $+0.69 \pm 3.20$ & $+0.53 \pm 0.98$ \\
\hline
\end{tabular}

Table 2. Comparison of the temperature difference distribution computed as the mean value and standard deviation of $\langle\Delta T>$ over each altitude range before and after applying the wave screening technique to the temperature profiles measured by GOMOS and SHADOZ over Ascension for October 11, 2004, illustrated in Figure 2 and Figure 3.
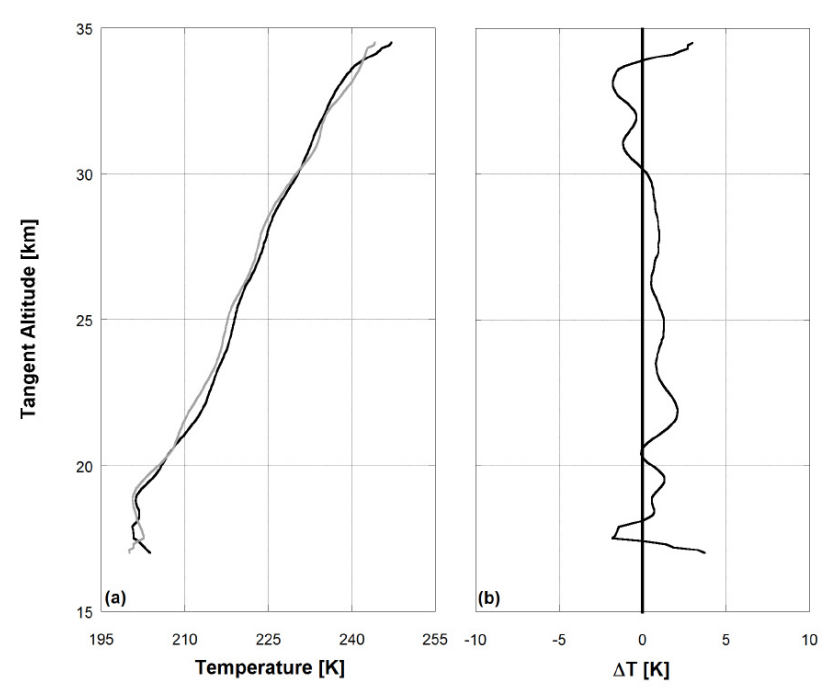

Figure 3. Same as Figure 2, but after removal of wavy structures.

between the two profiles can be estimated with higher accuracy, even for profiles not perfectly collocated and in presence of significant wavy structures. It should be noted that the mean difference values are not severely impacted by the wave removal.

We define perturbation as the small-scale vertical structures, determined with proposed wavelet analysis. Assuming that fluctuations in temperature profiles are generated by an ensemble of gravity waves, we can expect similar spectral properties of the temperature field at locations not far from each other $(<800 \mathrm{~km})$ during a time period of a few hours, as has been demonstrated previously in another related study [Sofieva et al. 2008]. In Figure 4, the perturbation profiles for GOMOS (black line) and SHADOZ (grey line) (relative to the profiles shown in Figure 2) are shown.

GOMOS and SHADOZ perturbations are dominated by periodicities with vertical wavelengths of a few $\mathrm{km}$ as observed previously in Figure 1.

In Figure 4, the difference in phase between GOMOS and SHADOZ wavy structure profiles is clearly visible. In this particular case, where the wave signals are very similar, it could be argued that the significant phase difference between the two profiles could be due to the time and distance separation between the measurements. As stated before, in the example reported in Figure 2, the peak-to-peak amplitude of the wavy structures is the order of $\pm 5 \mathrm{~K}$. The spatial distance between the two profiles is around $400 \mathrm{~km}$, whilst the temporal difference is of $\sim 9 \mathrm{~h}$. Although these profiles are not located at such large spatial and temporal distance from each other, the natural variability can contribute significantly to the temperature difference. In order to observe very similar small-scale structure without significant phase differences, the temperature profiles should be almost exactly collocated in time and in space. Sofieva et 


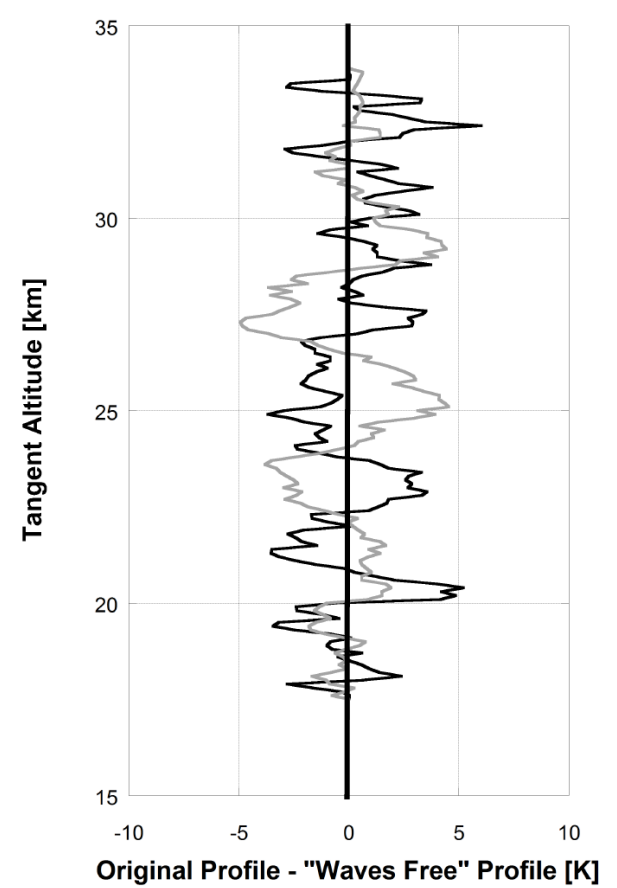

Figure 4. Wavy structure profiles: GOMOS (black line) and SHADOZ (grey line). Note that in this example the GOMOS and the SHADOZ perturbation profiles are obtained from the temperature profiles illustrated in Figure 2.

al. [2008] found that the small-scale structures in temperature profiles become different when the horizontal separation of measurements exceeds $20-30 \mathrm{~km}$.

As for the temperature, wavelet analysis has been applied also to the GOMOS HRTP air density profiles. In Figure 5, the GOMOS temperature (black line) and the air density (grey line) perturbation profiles (expressed in percentages) are displayed. The fluctuations are present in the density profile too, and, as expected, the GOMOS temperature and density fluctuations (expressed in \% for both quantities) are perfectly anti-correlated. This is consistent with the fact that the temperature profile is derived from the air density profile through the gas law and the assumption of hydrostatic equilibrium [Hauchecorne and Chanin 1980], and shows that the proposed method is not altering the physical relationships between thermodynamic variables.

We repeated the analysis for a set of collocated profiles, and the summary results are shown in Figure 6, for which a $300 \mathrm{~m}$ vertical grid has been selected. The averaging on a $300 \mathrm{~m}$ vertical grid was performed for sake of readability of the plot. Figure 6a shows the number of samples for a given altitude bin; Figure $6 \mathrm{~b}$ shows the average difference profile of temperature: the black squares represent the original data, whereas the grey circles correspond to the "wave-free" data. Finally, the horizontal lines represent \pm 1 standard deviation $(\sigma)$ calculated from the difference profiles of all coincident pairs within each altitude bin.

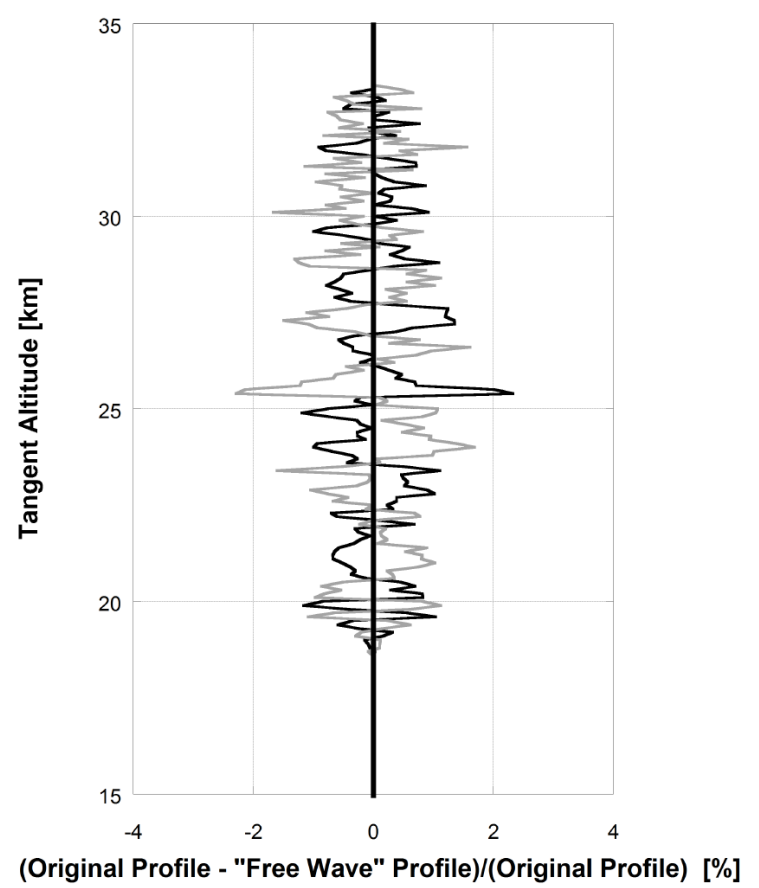

Figure 5. GOMOS HRTP temperature (black line) and neutral density (grey line) percentage perturbation profiles, obtained from the temperature profiles illustrated in Figure 2.

Between $19 \mathrm{~km}$ to $32 \mathrm{~km}$ altitudes, the bias distribution for original temperature profiles is $(0.20 \pm$ $0.90) \mathrm{K}$, while after the removal of wavy structure the bias distribution becomes $(0.38 \pm 0.47) \mathrm{K}$. Below $20 \mathrm{~km}$ and above $31 \mathrm{~km}$ the differences seem to be larger for both original and processed profiles, but this is probably due to the limited number of available measurements at low and high altitudes. Finally, Figure $6 \mathrm{c}$ shows the profiles of standard deviation of mean temperature difference of Figure $6 \mathrm{~b}$ at each altitude level for the original (black) and the wave-free (grey) data set.

Over the entire altitude range, the ratio between the mean of the wave-free standard deviation and the mean of the original standard deviation of the temperature differences, defined as $<\sigma_{\text {wave-free }}>/<\sigma_{\text {original }}>$, assumes a value of 0.71 , indicating an overall improvement of $\sim 30 \%$ in the accuracy of the estimates of the biases. This result indicates that the accuracy of the validation results depends not only on the measurement precision, but also on the natural variability of the atmospheric temperature field.

The improvement of the accuracy of validation results is important to evaluate the quality of the atmospheric parameters of the satellite measurements. Therefore the natural variability has to be taken into account. The temperature profiles might be more or less affected by geophysical variability due to the presence of the gravity waves and the magnitude of uncertainty of the bias is based also on the different conditions in the validation exercises, such as location and season. The out- 

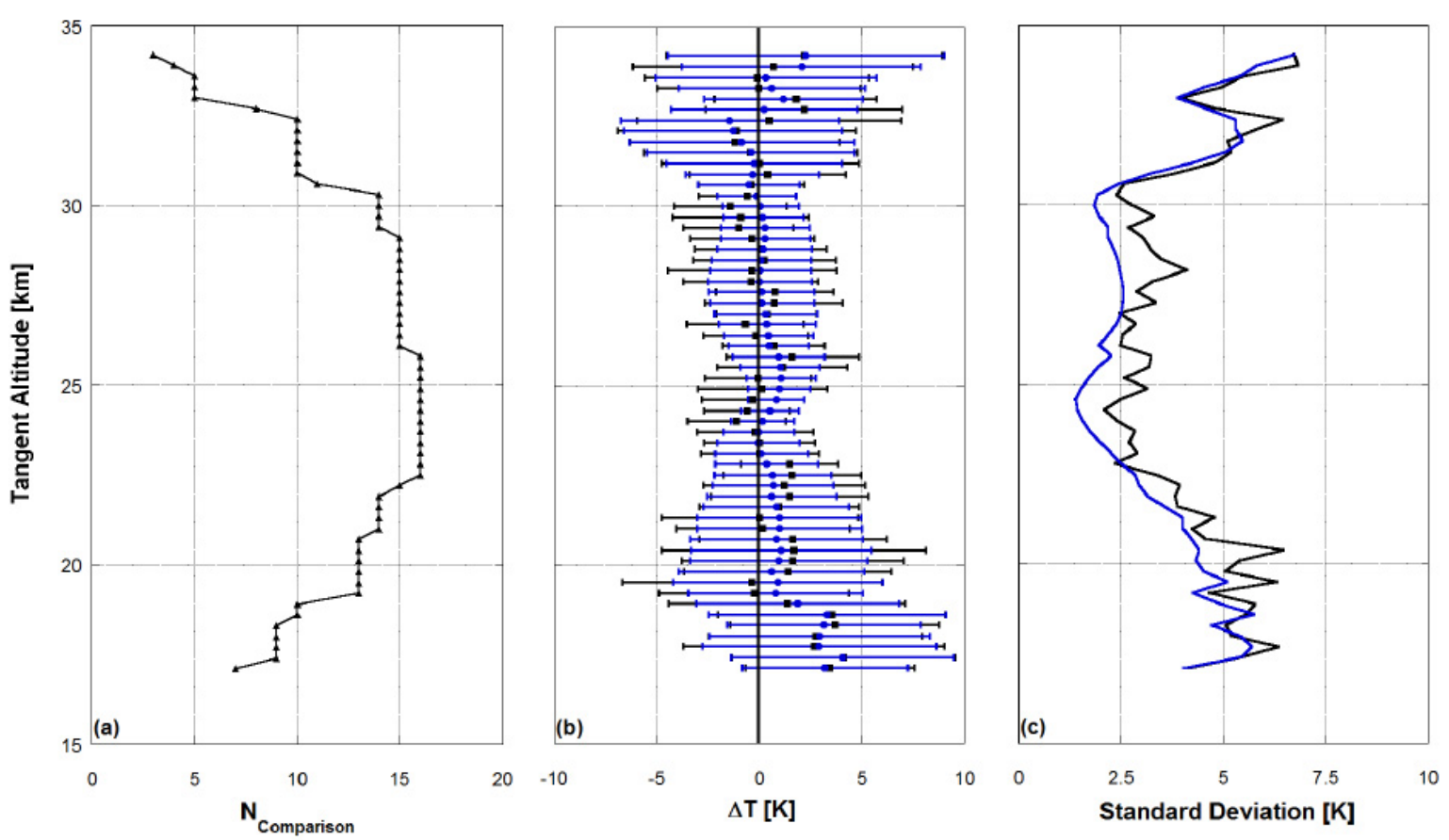

Figure 6. Comparison of the 16 GOMOS temperature profiles. (a) Number of collocated pairs; (b) mean differences between GOMOS and SHADOZ Temperature before (solid black squared dots) and after (solid blue round dots) applying the wavelet analysis. The spread of the average values at each height level, as represented by the standard deviation, is shown by continuous lines. (c) Comparison of the standard deviation of the mean temperature difference at each altitude level for the original (black line) and processed data (blue line).

come of the applied method is thus very useful to estimate the contribution due to the presence of small-scale fluctuations from the temperature and density profiles.

\section{Conclusions}

In this work, new method for the comparisons of temperature and density profile data from high vertical resolution measurements is described. The main purpose of the method is the detection and removal of wavy structures in order to improve instrument validation results, by decreasing the statistical uncertainties on mean differences.

This method has been applied to GOMOS HRTP and SHADOZ temperature profiles, in the common altitude range between 18 and $35 \mathrm{~km}$, using wavelet transforms.

The continuous wavelet transform possesses the ability to construct a space-frequency representation of a signal that offers very good space and frequency localization, so wavelet transforms can analyse localized non stationary structures of potentially great interest in the temperature signals. The wavelet approach should not be considered as a smoothing technique, as the CWT allows the characterisation and tracing of the localised features presented in a signal. The wavelet analysis of profiles is performed with a Morlet wavelet transformation.

The preliminary results presented in this work demonstrate that such a method can effectively be applied to stratospheric temperature data, improving the accuracy of GOMOS HRTP validation, when compared with SHADOZ soundings, by significantly reducing the uncertainty on bias estimates.

The temperature measurements considered in this work are characterised by a small common altitude range, due to the peculiarities of each technique. The possible use of Numerical Weather Prediction (NWP) temperature profiles would allow an artificial extension of the vertical range and, as a result, structures with vertical wavelengths higher than $5 \mathrm{~km}$ might be detected.

Furthermore, the extensive validation of GOMOS HRTP products with sounding and lidars, will be the focus for our future research. We finally conclude saying that the GOMOS data set represents a very valuable source of information for atmospheric science studies. Particularly, the GOMOS HRTP measurements could be used to yield information about the vertical wavenumbers of the atmospheric waves and provide constraints for the parameterisation of gravity waves in climateprediction models. In particular, gravity wave scales, amplitudes, fluxes, vertical propagation, and variations with altitude can be addressed with these space-based observations.

Acknowledgements. The authors would like to express their gratitude to Lidia Saavedra de Miguel, Gareth Davies, Marta De Laurentis, Gabriele Brizzi, Angelika Dehn, and Thorsten Fehr for their support and collaboration. The author would also like to thank the principal investigators of the SHADOZ sondes. Finally, we thank Victoria Sofieva for helpful comments on the manuscript. 


\section{References}

Alexander, M.J., J. Gille, C. Cavanaugh, M. Coffey, C. Craig, T. Eden, G. Francis, C. Halvorson, J. Hannigan, R. Khosravi, D. Kinnison, H. Lee, S. Massie, B. Nardi, J. Barnett, C. Hepplewhite, A. Lambert and V. Dean (2008). Global estimates of gravity wave momentum flux from High Resolution Dynamics Limb Sounder observations, J. Geophys. Res., 113, D15S18. Alexander, M.J., M. Geller, C. McLandress, S. Polavarapu, P. Preusse, F. Sassi, K. Sato, S. Eckermann, M. Ern, A. Hertzog, Y. Kawatani, M. Pulido, T.A. Shaw, M. Sigmond, R. Vincent and S. Watanabe (2010). Recent developments in gravity-wave effects in climate models and the global distribution of gravity-wave momentum flux from observations and models, Q. J. Roy. Meteor. Soc., 136, 1103-1124.

Alpers, M., R. Eixmann, C. Fricke-Begemann, M. Gerding and J. Hoffner (2004). Temperature lidar measurements from 1 to $105 \mathrm{~km}$ altitude using resonance, Rayleigh, and Rotational Raman scattering, Atmos. Chem. Phys., 4, 793-800.

Bertaux, J.L., A. Hauchecorne, F. Dalaudier, C. Cot, E. Kyrölä, D. Fussen, J. Tamminen, G.W. Leppelmeier, V. Sofieva, S. Hassinen, O. Fanton d'Andon, G. Barrot, A. Mangin, B. Théodore, M. Guirlet, O. Korablev, P. Snoeij, R. Koopman and R. Fraisse (2004). First results on GOMOS/ENVISAT, Adv. Space Res., 33, 1029-1035.

Bertaux, J.L., E. Kyrölä, D. Fussen, A. Hauchecorne, F. Dalaudier, V. Sofieva, J. Tamminen, F. Vanhellemont, O. Fanton d'Andon, G. Barrot, A. Mangin, L. Blanot, J.C. Lebrun, K. Pérot, T. Fehr, L. Saavedra, G.W. Leppelmeier and R. Fraisse (2010). Global ozone monitoring by occultation of stars: an overview of GOMOS measurements on ENVISAT, Atmos. Chem. Phys., 10, 12091-12148.

Borchi, F., J.P. Pommereau, A. Garnier and M. Pinharanda (2005). Evaluation of SHADOZ sondes, HALOE and SAGE II ozone profiles at the tropics from SAOZ UV-Vis remote measurements onboard long duration balloons, Atmos. Chem. Phys., 5, 1381-1397.

Christy, J.R., and W.B. Norris (2009). Discontinuity issues with Radiosonde and satellite temperatures in the Australian region 1979-2006, J. Atmos. Oceanic Technol., 26, 508-522.

Dalaudier, F., V. Sofieva, A. Hauchecorne, E. Kyrölä, L. Blanot, M. Guirlet, C. Retscher and C. Zehner (2006). High-resolution density and temperature profiling in the stratosphere using bi-chromatic scintillation measurements by GOMOS, Proceedings of the First Atmospheric Science Conference, European Space Agency, ISBN92-9092-939-1-ISSN1609-042X.
Dials, M.A., J.C. Gille, J.J. Barnett and J.G. Whitney (1998). Description of the high resolution dynamics limb sounder (HIRDLS) instrument, In: Proceedings of SPIE, 3437, 84-91.

Durre, I., R.S. Vose and D.B. Wuertz (2006). Overview of the Integrated Global Radiosonde Archive, J. Climate, 19, 53-68.

Fetzer, E.J., and J.C. Gille (1994). Gravity wave variance in LIMS temperatures. Part I: Variability and comparison with background winds, J. Atmos. Sci., 51, 2461-2483.

Fritts, D.C., and J. Alexander (2003). Gravity wave dynamics and effects in the middle atmosphere, Rev. Geophys., 41 (1), 1003; doi:10.1029/2001RG000106.

Geller, M.A., M.J. Alexander, P.T. Love, J. Bacmeister, M. Ern, A. Hertzog, E. Manzini, P. Preusse, K. Sato, A. Scaife and T. Zhou (2013). A comparison between gravity wave momentum fluxes in observations and climate models, J. Climate, 26, 6383-6405.

Hauchecorne, A., and M.L. Chanin (1980). Density and temperature profiles obtained by lidar between 35 and 70 km, Geophys. Res. Lett., 8, 565-569.

Hendrick, F., J.P. Pommereau, F. Goutail, R.D. Evans, D. Ionov, A. Pazmino, E. Kyrö, G. Held, P. Eriksen, V. Dorokhov, M. Gil and M. Van Roozendael (2011). NDACC/SAOZ UV-visible total ozone measurements: improved retrieval and comparison with correlative ground-based and satellite observations, Atmos. Chem. Phys., 11, 5975-5995.

Holton, J.R., and C. Mass (1976). Stratospheric vacillation cycles, J. Atmos. Sci., 33, 2218-2225.

Holton, J.R., and M.J. Alexander (2000). The role of waves in the transport circulation of the middle atmosphere, Geophys M., 123, 21-35.

Hudson, S.R., M.S. Town, V.P. Walden and S.G. Warren (2004). Temperature, humidity, and pressure response of radiosondes at low temperatures, J. Atmos. Oceanic Technol., 21, 825-836.

Kishore, P., S.P. Namboothiri, J.H. Jiang, V. Sivakumar and K. Igarashi (2009). Global temperature estimates in the troposphere and stratosphere: a validation study of COSMIC/FORMOSAT-3 measurements, Atmos. Chem. Phys., 9, 897-908.

Kitchen, M. (1989). Representativeness errors for radiosonde observations, Q. J. Roy. Meteor. Soc., 115, 673-700.

Knuteson, R.O., H.E. Revercomb, F.A. Best, N.C. Ciganovich, R.G. Dedecker, T.P. Dirkx, S.C. Ellington, W.F. Feltz, R.K. Garcia, H.B. Howell, W.L. Smith, J.F. Short and D.C. Tobin (2004a). Atmospheric Emitted Radiance Interferometer. Part I: Instrument design, J. Atmos. Oceanic Technol., 21, 1763-1776.

Knuteson, R.O., H.E. Revercomb, F.A. Best, N.C. 
Ciganovich, R.G. Dedecker, T.P. Dirkx, S.C. Ellington, W.F. Feltz, R.K. Garcia, H.B. Howell, W.L. Smith, J.F. Short and D.C. Tobin (2004b). Atmospheric Emitted Radiance Interferometer. Part II: Instrument performance, J. Atmos. Oceanic Technol., 21, 1777-1789.

Kumar, G.K., M.V. Ratnam, A.K. Patra, S.V. B. Rao and J. Russel (2008). Mean thermal structure of the lowlatitude middle atmosphere studied using Gadanki Rayleigh lidar, Rocket, and SABER/TIMED observations, J. Geophys. Res. Atmos., 113, D23; doi:10. 1029/2008JD010511.

Kursinski, E.R., G.A. Hajj, J.T. Schofield, R.P. Linfield and K.R. Hardy (1997). Observing Earth's Atmosphere with Radio Occultation Measurements Using the Global Positioning System, J. Geophys. Res., 102, 23429-23465.

Kyrölä, E., J. Tamminen, G.W. Leppelmeier, V. Sofieva, S. Hassinen, J.L. Bertaux, A. Hauchecorne, F. Dalaudier, C. Cot, O. Korablev, O. Fanton d'Andon, G. Barrot, A. Mangin, B. Théodore, M. Guirlet, F. Etanchaud. P. Snoeij, R. Koopman, L. Saavedra, R. Fraisse, D. Fussen and F. Vanhellemont (2004). GOMOS on Envisat: An overview, Adv. Space Res., 33, 1020-1028.

Kyrölä, E., J. Tamminen, G.W. Leppelmeier, V. Sofieva, S. Hassinen, A. Seppälä, P.T. Verronen, J.-L. Bertaux, A. Hauchecorne, F. Dalaudier, D. Fussen, F. Vanhellemont, O. Fanton d'Andon, G. Barrot, A. Mangin, B. Theodore, M. Guirlet, R. Koopman, L.S. de Miguel, P. Snoeij, T. Fehr, Y. Meijer and R. Fraisse (2006). Night time ozone profiles in the stratosphere and mesosphere by the Global Ozone Monitoring by Occultation of Stars on Envisat, J. Geophys. Res., 111, D24306.

Lanzante, J., S. Klein and D.J. Seidel (2003). Temporal homogenization of monthly radiosonde temperature data. Part I: Methodology, J. Climate, 16, 224240.

McDonald, A.J., B. Tan and X. Chu (2010). Role of gravity waves in the spatial and temporal variability of stratospheric temperature measured by COSMIC/ FORMOSAT 3 and Rayleigh lidar observations, J. Geophys. Res., 115, D19118.

Moradi, I., S.A. Buehler, V.O. John and S. Eliasson (2010). Comparing upper tropospheric humidity data from microwave satellite instruments and tropical radiosondes, J. Geophys. Res., 115, D24310.

Preusse, P., S. Schroeder, L. Hoffmann, M. Ern, F. FriedlVallon, H. Oelhaf, H. Fischer and M. Riese (2009). New perspectives on gravity wave remote sensing by spaceborne infrared limb imaging, Atmos. Meas. Tech. Discuss., 2, 825-856.

Rauthe, M., M. Gerding and F.J. Lubken (2008). Sea- sonal changes in gravity wave activity measured by lidars at mid-latitudes, Atmos. Chem. Phys., 8, 67756787.

Ridolfi, M., U. Blum, B. Carli, V. Catoire, S. Ceccherini, H. Claude, C. De Clercq, K.H. Fricke, F. Friedl-Vallon, M. Iarlori, P. Keckhut, B. Kerridge, J.C. Lambert, Y.J. Meijer, L. Mona, H. Oelhaf, G. Pappalardo, M. Pirre, V. Rizi, C. Robert, D. Swart, T. von Clarmann, A. Waterfall and G. Wetzel (2007). Geophysical validation of temperature retrieved by the ESA processor from MIPAS/ENVISAT atmospheric limb-emission measurements, Atmos. Chem. Phys., 7, 4459-4487.

Schreiner, W., C. Rocken, S. Sokolovskiy, S. Syndergaard and D. Hunt (2007). Estimates of the precision of GPS radio occultations from the COSMIC/ FORMOSAT-3 mission, Geophys. Res. Lett., 34, L04808.

Sofieva, V.F., A.S. Gurvich, F. Dalaudier and V. Kan (2007a). Reconstruction of internal gravity wave and turbulence parameters in the stratosphere using GOMOS scintillation measurements, J. Geophys. Res., 112, D12113.

Sofieva, V.F., E. Kyrölä, S. Hassinen, L. Backman, J. Tamminen, A. Seppälä, L. Thölix, A.S. Gurvich, V. Kan, F. Dalaudier, A. Hauchecorne, J.-L. Bertaux, D. Fussen, F. Vanhellemont, O. Fanton d'Andon, G. Barrot, A. Mangin, M. Guirlet, T. Fehr, P. Snoeij, L. Saavedra, R. Koopman and R. Fraisse (2007b). Global analysis of scintillation variance). Indication of gravity wave breaking in the polar winter upper stratosphere, Geophys. Res. Lett., 34, L03812.

Sofieva, V.F., F. Dalaudier, R. Kivi and E. Kyröla (2008). On the variability of temperature profiles in the stratosphere: Implication for validation, Geophys. Res. Lett., 35, L23808.

Sofieva, V.F., J. Vira, F. Dalaudier, A. Hauchecorne and GOMOS team (2009). Validation of GOMOS/Envisat High-Resolution Temperature Profiles (HRTP) Using Spectral Analysis, New Horizons in Occultation Research, 97-107.

Sofieva, V.F., A.S. Gurvich and F. Dalaudier (2010). Mapping gravity waves and turbulence in the stratosphere using satellite measurements of stellar scintillation, Physica Scripta, vol. 2010, T142.

Spencer, R.W., J.R., Christy and N.C. Grody (1990). Global atmospheric temperature monitoring with satellite microwave measurements: Method and results 1979-84, J. Climate, 3, 1111-1128.

Stockwell, R.G., L. Mansinha and R.P. Lowe (1996). Localization of the Complex Spectrum: The S Transform, IEEE T. Signal Proc., 44, 998-1001.

Thompson, A.M., J.C. Witte, R.D. McPeters, S.J. Olt- 
mans, F.J. Schmidlin, J.A. Logan, M. Fujiwara, V.W.J.H. Kirchhoff, F. Posny, G.J.R. Coetzee, B. Hoegger, S. Kawakami, T. Ogawa, B.J. Johnson, H. Vömel and G. Labow (2003a). Southern Hemisphere Additional Ozonesondes (SHADOZ) 1998-2000 tropical ozone climatology 1. Comparison with Total Ozone Mapping Spectrometer (TOMS) and groundbased measurements, J. Geophys. Res., 108, 8238; doi:10.1029/2001JD000967.

Thompson, A.M., J.C. Witte, S.J. Oltmans, F.J. Schmidlin, J.A. Logan, M. Fujiwara, V.W.J.H. Kirchhoff, F. Posny, G.J.R. Coetzee, B. Hoegger, S. Kawakami, T. Ogawa, J.P.F. Fortuin and H.M. Kelder (2003b). Southern Hemisphere Additional Ozonesondes (SHADOZ) 1998-2000 tropical ozone climatology 2. Tropospheric variability and the zonal wave-one, J. Geophys. Res., 108, 8241; doi:10.1029/2002JD002241.

Thompson, A.M., J.C. Witte, S.J. Oltmans and F.J. Schmidlin (2004). Shadoz - A Tropical OzonesondeRadiosonde Network For The Atmospheric Community, B. Am. Meteorol. Soc., 1549; doi:10.1175/ BAMS-85-10-1549.

Thompson, A.M., J.C. Witte, H.G.J. Smit, S.J. Oltmans, B.J. Johnson, V.W.J.H. Kirchhoff and F.J. Schmidlin (2007). Southern Hemisphere Additional Ozonesondes (SHADOZ) 1998-2004 tropical ozone climatology: 3. Instrumentation, station-to-station variability, and evaluation with simulated flight profiles, J. Geophys. Res., 112, D03304; doi:10.1029/2005JD007042.

Thompson, D.W.J., D.J. Seidel, W.J. Randel, C. Zhi Zou, A.H. Butler, C. Mears, A. Osso, C. Long and R. Lin (2012). The mystery of recent stratospheric temperature trends, Nature, 491, 692-697.

Tiefenau, H.K.E., and A. Gebbeken (1989). Influence of Meteorological Balloons on Temperature Measurements with Radiosondes: Nighttime Cooling and Daylight Heating, J. Atmos. Oceanic Technol., 6, 36-42.

Torrence, C., and G.P. Compo (1998). A Practical Guide to Wavelet Analysis, B. Am. Metereol. Soc., 79, 61-78.

WMO, World Meteorological Organization (2008). Guide to Meteorological Instruments and Methods of Observation, 7th ed. WMO 8, Geneva.

Wright, C.J., M.B. Rivas and J.C. Gille (2011). Intercomparisons of HIRDLS, COSMIC and SABER for the detection of stratospheric gravity waves, Atmos. Meas. Tech., 4, 1581-159.

Wu, D.L., and J.W. Waters (1996). Gravity wave scale temperature fluctuations seen by the UARS MLS, Geophys. Res. Lett., 23, 3289-3292.

Zhang, S.D., C. Huang and F. Yi (2006). Radiosonde observations of vertical wave number spectra for gravity waves in the lower atmosphere over Central
China, Annales Geophysicae, 24, 3257-3265.

Zink, F., and R.A. Vincent (2001). Wavelet analysis of stratospheric gravity wave packets over Macquarie Island: 2. Intermittency and mean-flow accelerations, J. Geophys. Res., 106, D10.

\footnotetext{
${ }^{\star}$ Corresponding author:

Rosario Q. Iannone, SERCO S.p.A., Frascati, Italy; email: rosarioquirino.iannone@serco.com.

C) 2014 by the Istituto Nazionale di Geofisica e Vulcanologia. All rights reserved.
} 